\title{
PERÍODO REPRODUTIVO E FECUNDIDADE DO ERMITÃO CALCINUS TIBICEN (HERBST, 1791) (DECAPODA, ANOMURA) PROVENIENTE DE ITACARÉ, BAHIA, BRASIL
}

\author{
Santos, M.P. ${ }^{1,}{ }^{*} ;$ Monteiro, J.O. ${ }^{1} \&$ Fransozo, V. ${ }^{1}$ \\ ${ }^{1}$ Universidade Estadual do Sudoeste da Bahia (UESB), Campus Vitória da Conquista, Laboratório de Zoologia. \\ *Autor correspondente: teusantos11@hotmail.com
}

\begin{abstract}
Os ermitões são suscetíveis a ataques e predação, devido ao seu abdome mole e descalcificado. Assim, utilizam-se conchas de gastrópodes como abrigo. Este estudo investigou aspectos reprodutivos tais como período reprodutivo e fecundidade do ermitão C. tibicen no município de Itacaré, litoral Sul da Bahia. A amostragem foi realizada a cada dois meses, de outubro de 2013 a setembro de 2014, durante o período da maré baixa. As coletas foram realizadas aleatoriamente e manualmente por dois coletores durante $30 \mathrm{~min}$. No laboratório, os ermitões foram retirados de suas conchas, identificados, mensurados quanto ao tamanho do escudo cefalotorácico (CEC) e o sexo de cada indivíduo foi acessado. Os ovos, aderidos aos pleópodos das fêmeas, foram classificados em três estágios embrionários (inicial,intermediário e final) e contados, a fim de se calcular a fecundidade (número de ovos postos por fêmea embrionada). Os dados foram plotados em gráficos e as funções linear e potência foram ajustadas aos mesmos na tentativa de verificar um possível modelo sobre a fecundidade de $C$. tibicen. O teste $t$ de Student foi utilizado para testar o ajuste da linha de tendência a fim de confirmar a existência da mesma. Um total de 651 indivíduos foram coletados (216 machos, 210 fêmeas não embrionadas e 225 fêmeas embrionadas). Verificou-se uma descontinuidade na reprodução, com ausência de fêmeas embrionadas no mês de julho (inverno) e maior incidência em setembro e outubro (primavera). Este resultado confirma estudos prévios de outros autores para a mesma espécie, caracterizando um período reprodutivo sazonal. Para a análise de fecundidade, apenas os ovos em estágio inicial de desenvolvimento foram utilizados. A maior média de fecundidade foi reportada para fevereiro (verão) $(747,96 \pm 379,36$ ovos), embora neste período, o número de fêmeas embrionadas tenha sido menor, comparado aos outros meses. As regressões ajustadas para a relação do "CEC vs. número de ovos postos por fêmea" não indicaram nenhuma tendência matemática, não havendo relação direta entre a fecundidade e o tamanho das fêmeas embrionadas. Tal fato deve-se à ocorrência de variação do número de ovos por fêmea dentro de uma mesma classe de tamanho. Esta variação pode ser influenciada tanto pelo processo de desova múltipla em um mesmo período reprodutivo, quanto pela ocupação de uma concha inadequada.
\end{abstract}

Palavras-chave: média de fecundidade, Nordeste, Paguroidea, reprodução, sazonal. 